Series: Influenza epidemics, past and present

ORIGINAL ARTICLE

\title{
The Spanish Flu at Camp Grant, Illinois: A military and civilian response
}

\author{
Anne STEWART \\ The University of Virginia, Charlottesville, USA
}

One hundred years after the "Spanish influenza" pandemic, the crisis is still known as one of the most devastating attacks on humanity. Coinciding with a world at war, the context in which the pandemic occurred was perfect for the spread of a deadly disease. As Gwyneth Malbrath argues in her paper in this series, circumstances of over-crowded military camps within the United States and in Europe forced soldiers to battle their own bodies while also fighting other nations. Thus, the flu brought about its own war - with more soldiers dying from disease than from battlefield injuries. This paper examines the effect and response to flu that occurred at Camp Grant, a United States military base in Illinois. There, soldiers, nurses, and the public collaborated to fight one of the most virulent and deadly strains of influenza that the world had ever seen.

\section{CAMP GRANT}

The first case of the flu at Camp Grant in Illinois was reported on September 21, 1918, only days after new recruits arrived from Camp Devens, near Boston. The new recruits had been sent to Camp Grant to attend the Infantry Central Officers Training School. Unfortunately, they brought the deadly flu with them. ${ }^{1}$

The flu spread quickly through the close quarters in which the soldiers lived, affecting, in particular, the 5th Limited Service Regiment whose barracks were adjoining the Infantry Central Officers' Training School in the northern part of the camp. ${ }^{2}$ According to a report submitted by the Office of the Surgeon General in November of 1918, within 48 hours of the first case being reported, there were cases inside every organization in the

J-STAGE advance published 13 February 2020. entire camp. ${ }^{3}$ On September 27, six days after its first appearance, 984 cases were admitted to the camp hospital. In fact, in "six days, the hospital went from 610 occupied beds to 4,102 occupied, almost five times more patients than it had ever cared for." ${ }^{\prime 4}$ Young and previously unexposed to the virus, the men who were now in constant contact with their companions and under immense physical strain due to the demands of military training, were perfect targets for the disease. Moreover, their robust immune systems were ready to fight the virus, leading to what we now know as acute respiratory distress syndrome (ARDS) caused by the massive release of inflammatory cytokines.

As hundreds of soldiers in Camp Grant succumbed to the virus, military leaders took prompt action, forbidding travel to and from the base except for extreme circumstances, and closing all public buildings around the camp, including some in nearby Chicago. ${ }^{5}$ When the military hospital exceeded maximum capacity in a matter of days, healthy soldiers vacated barracks to live in tents, while the barracks became makeshift hospitals. According to historian John Barry, "There were too few sheets for the beds, so the Red Cross ordered six thousand from Chicago. There were too few beds, so several thousand cots were crammed into every square inch of corridor, storage area, meeting room, office and veranda." ${ }^{6}$ Yet, there still were not enough beds to accommodate the sick. Twenty-eight young recruits died at Camp Grant on October 1, 1918, and 40 more died the following day. In just over a week, the total dead had reached more than $100 .^{7}$

\section{CALLING FOR HELP}

With military physicians collapsing from overwork and thirty-five nurses themselves sick, the camp's leaders 
called for medical personnel and nurses from surrounding cities to help. They needed as many physicians and nurses as they could find who were able and willing to care for the soldiers. Army Surgeon General, William C. Gorgas, himself implemented sanitation regulations and set up camps to train volunteers to care for the sick soldiers. These provided volunteers with basic medical knowledge, but not nearly enough could be provided in the limited time available.

As demands for nurses reached new heights, student nurses who were at Camp Grant for training were put to work. Among these was Maury Schwarz, a young nursing student who had recently enrolled in the Army School of Nursing. At Camp Grant, Schwarz began to work on the wards immediately, receiving only "on the job" training as she cared for hundreds of young soldiers struck down with flu. ${ }^{8}$ Later, African American female nurses were sent to Camp Grant. Recruiting African American nurses for the Army Nurse Corps was unheard of at the time; in the Jim Crow era, there were strict rules about segregation of the races, and the Army had not been prepared to enlist them. Rising to the occasion, and ignoring racial prejudice, these newly recruited African American nurses performed admirably, later receiving recognition for their display of exceptional service and professional demeanor during the chaos of the pandemic. ${ }^{9}$

\section{INFLUENZA TREATMENT AT CAMP GRANT}

At the time of the influenza pandemic, the world was on the brink of discoveries in modern medicine, with the medical and scientific communities only recently accepting the germ theory of disease. The new technology of the x-ray, urinalysis, and blood tests all helped to identify diseases and their etiologies. The medical community, however, was not prepared for the extent and severity of the Spanish influenza. Technology had not yet been developed to understand the cause and symptoms of a virus or how to treat it. There were no antiviral medications, no vaccines for flu, and no antibiotics. Instead, medical professionals relied on basic treatments to alleviate the discomfort and pain that the flu inflicted. These included alcohol baths, ice packs, soups and other fluids, aspirin, and deep breathing exercises. In cases of acute respiratory distress, sometimes digitalis and oxygen were administered. ${ }^{10}$ In short, nursing care was critical in the attempt to bring as much comfort to the patients as possible as their bodies fought the virus on their own.

Prevention of further spread of the infection was the priority. Nurses and physicians caring for patients with the flu were required to wear gauze masks in an effort to prevent the virus's airborne spread. Soldiers at Camp Grant were inspected twice daily for any symptoms of the flu, and those discovered to be symptomatic were isolated from the healthy.

\section{AN EMERGENT PUBLIC RESPONSE}

Citizens and organizations surrounding Camp Grant participated in an emergent response. ${ }^{11}$ Local Red Cross volunteers made and distributed gauze masks for medical and nursing personnel, set up a large tent with telephones to contact relatives of the sick, and recruited nurses and volunteers to help in the camp. The War Camp Community Service (WCCS), an organization initially set up to provide moral support for soldiers during and after the war, also provided assistance. From the onset, the WCCS offered active support, primarily in the area of transportation, providing cars and trucks to carry patients' families, volunteers, and medical personnel into and out of the base each day. ${ }^{12}$ Individual citizens also contributed a great deal to the influenza response around the camp. Some volunteered to cook or write letters for the soldiers. Others made donations to the Red Cross or offered housing to those families and medical professionals who came from out of town.

\section{CONCLUSION}

At Camp Grant, the flu persisted through September and early October 1918, eventually subsiding in late October. The number of flu cases handled at Camp Grant totaled more than $10,600 .{ }^{13}$ The response was a collaborative, emergent effort, including military physicians and nurses, new student nurse recruits from the Army School of Nursing, African American nurse volunteers, the local Red Cross, the War Camp Community Service, and the general public. All were needed to deal with the explosive and deadly pandemic.

\section{REFERENCES}

1 University of Michigan Center for the History of Medicine, Abstract from Report on Influenza Epidemic at Camp Grant, Illinois, September 21, 1918 to November 5, 1918. (University of Michigan Library: Michigan Publishing). Available from: https://quod.lib.umich.edu/f/flu/3160flu.0014.613/1 (Accessed July 29, 2019).

2 Epidemiological Report [Camp Grant, Illinois] RG 112 Records of the Office of the Surgeon General, Army. Available from: https://hdl.handle.net/2027/spo.2160flu.0014.612: 1-2. 
(Accessed July 29, 2019).

3 University of Michigan, Abstract from the Report on the Influenza Epidemic at Camp Grant, September 21, 1918. (accessed July 29, 2019).

4 John Barry, The Great Influenza: The Epic Story of the Deadliest Plague in History (New York: The Penguin Group, 2004): 214.

5 Thomas Powers, "Nuggets of History: Camp Grant and the 1918 Influenza Pandemic," (Rockford Historical Society, 2008). Available from: https://www.rhsil.org/uploads/2/6/4/3/ 26435469/2008_-_vol_46_-_no_4.pdf (Accessed July 29, 2019).

6 John Barry, The Great influenza. (2004): 214.

7 Thomas Powers, "Nuggets of History" np.

8 Maury Schwarz Collection, The Eleanor Crowder Bjoring Center for Nursing Historical Inquiry, University of Virginia
School of Nursing.

9 Thomas Powers, "Nuggets of History," np.

10 Arlene Keeling, "“Alert to the Necessities of the Emergency': U.S. Nursing during the 1918 Influenza Pandemic," Public Health Reports. (2010 Supplement 3, volume 125): 105-111.

11 Barbra Mann Wall "Disasters, Nursing, and Community Responses: A Historical Perspective." Nursing History Review. 23, 1 (2015): 11-27 (quote p. 11).

12 Thomas Powers, "Nuggets of History." np.

13 Epidemiological Report [Camp Grant, Illinois] RG 112 Records of the Office of the Surgeon General, Army. Available from: https:/hdl.handle.net/2027/spo.2160flu.0014.612: 1-2 (Accessed July 29, 2019). 